The Myth of Progress: 2001: A Space Odyssey

Robert Poole

Limiting Outer Space ed. Alexander C. T. Geppert (Palgrave Macmillan, forthcoming, 2018).

Corrected pre-print.

The 1968 film and novel 2001: A Space Odyssey marked the cultural apex of the Space Age. ${ }^{1}$ It was an Anglo-American project, the joint creation of the leading film director Stanley Kubrick (1928-1999), famous for the nuclear war satire $D r$ Strangelove, and the leading science fiction and popular science writer Arthur C. Clarke (1917-2008), famous for his 1945 prediction of the communications satellite. $^{2}$ (Figure 1: Arthur C. Clarke). 2001 was the first science fiction film to have genuinely plausible special effects. Its making was a miniature space program in its own right, breaking all previous records for production costs and generating considerable public interest; it was, in relation to the science of its day, the most scientifically accurate feature film ever made. ${ }^{3}$ It was made in the mid-1960s at a time when space programs were accelerating on all fronts. The early humancannonball style flights of the Mercury and Vostok programs were over and the more complex Gemini and Voshkod missions saw the first astronauts performing

The principal printed sources are: Arthur C. Clarke, 2001: A Space Odyssey, London: Hutchinson, 1968; Jerome Agel, The Making of Kubrick's 2001, New York: Signet, 1970; Arthur C. Clarke, The Lost Worlds of 2001, London: Sidgwick \& Jackson, 1972; Piers Bizony, 2001: Filming the Future, London: Aurum Press, 1994; David G. Stork, ed., Hal's Legacy: 2001's Computer as Dream and Reality, Cambridge, MA: MIT Press, 1997; Alison Castle, The Stanley Kubrick Archive, London: Taschen, 2005; Anthony Frewin, Are We Alone? The Stanley Kubrick Extraterrestrial Intelligence Interviews, London: Elliott and Thompson, 2005; Robert Volker, ed., Stanley Kubrick's 2001: A Space Odyssey: New Essays, Oxford: Oxford University Press, 2006; Peter Kramer, 2001: A Space Odyssey, Basingstoke: Palgrave Macmillan, 2010.

2 John Baxter, Stanley Kubrick: A Biography, London: Harper Collins, 1997; Arthur C. Clarke, Greetings, Carbon-Based Bipeds! London: Harper Collins, 1999; Neil McAleer, Odyssey: The Authorized Biography of Arthur C. Clarke, London: Victor Gollancz, 1992; Arthur C. Clarke, 'Extra-Terrestrial Relays: Can Rocket Stations Give World-wide Radio Coverage?', Wireless World 51.10 (October 1945), 305-8.

3 David Kirby, Lab Coats in Hollywood: Science, Scientists and Cinema, Cambridge, MA: MIT Press, 2011, 1-8. 
orbital maneuvers, walking in space, and sending back stunning pictures of the blue planet below. The first space probes had recently reached Venus and Mars, their senders still optimistic about detecting signs of life. 2001 opened across the United States in the spring of 1968, and across the rest of the world in the spring and summer, during a lull in the US manned space program caused by the Apollo fire disaster of January 1967. 2001 was for a time the biggest show in space; it attracted record audiences, and was still running in many cities more than year later as the Apollo 11 astronauts landed on the Moon. ${ }^{4}$ Arthur Clarke was then on the television commentary team for CBS, a prophet in his own future, his words broadcast round the world on the communications satellites whose advent he had predicted in 1945. Never have fiction and reality run so close; there is a case for saying that the real winner of the Space Race was 2001: A Space Odyssey. ${ }^{5}$

At its inception in 1964, 2001 had promised to be a kind of propagandist docu-drama on the model of Destination Moon (1950) and The Conquest of Space (1955), designed with the best available scientific advice to make the case for space travel in a popular form. ${ }^{6}$ It was at first trailed as Journey Beyond the Stars, an exciting saga of the exploration of the solar system, and it was the prospect of realistic scenes of space travel, as depicted on posters by the NASA artist Robert McCall (1919-2010), that initially brought audiences flooding in. (Figure 2: poster for 2001: A Space Odyssey) Keen to stay ahead of present-day reality however, Kubrick and Clarke had raised their sights further into the future - to the moment of first contact with extraterrestrial intelligence, which at that time was widely anticipated (particularly in Europe) as a consequence of space travel. They explained that their aim was to prepare the public for the impact of such an encounter, which threatened shock but promised enlightenment. Kubrick went as far as filming dozens of interviews with leading scientists and philosophers on the subject of extraterrestrial intelligence for a documentary prologue, although the

Kramer, 2001: A Space Odyssey, 90-2.

Howard E. McCurdy, Space and the American Imagination, Washington, DC: Smithsonian Institution Press, 1997.

lbid., 45-8, 67-8, 193-5. 
plan was in the end scrapped, leaving a legacy of interviews of considerable historical interest. ${ }^{7}$

Also scrapped, to the dismay of the serious space community, were almost all the traditional explanations about the technology of space travel. The 1940s and 1950s had been the heyday of 'hard' science fiction and the gadget story, and the much-publicized attention to technological detail in the production of 2001 had led the public to expect something similar, but there were to be no 'now tell me, professor' moments in Kubrick's film. ${ }^{8}$ Even the narrative voiceovers, regarded as essential by Kubrick's advisors in order to explain the obscure plot, were abandoned. 'This isn't a proper science fiction movie at all' thought one leading science fiction writer, Lester del Rey. 'A wasted opportunity' complained another, Frederick Pohl. Kubrick described such reactions as 'obtuse.' ${ }^{9}$ His aim, concealed from his eager technical staff, was to achieve a future environment plausible enough to allow the viewers to take it for granted and concentrate on the real story. An early section depicting lunar exploration in the near future came closest to satisfying expectations, with its glorious space ballet to the soundtrack of Johann Strauss' Blue Danube waltz and its realistically-styled account of the discovery of an alien artifact on the Moon. The subsequent long voyage to Jupiter (in the novel, Saturn) to investigate the apparent source of the alien artifact also contained plenty of conventional space interest, although the plot's central conflict was not between humans and aliens but between the astronauts and their rogue computer.

The recognizably science fiction elements of the film were framed by a 20minute wordless prologue entitled 'The Dawn of Man', set at the dawn of human evolution in Africa, and by a mysterious, psychedelic final sequence which came to be known as 'the ultimate trip'. The film ended with the image of a human fetus floating in space above the Earth, gazing down on the entire globe as the eyes of humanity, in the persons of the Apollo 8 astronauts, would do so for the first time

The interviews are collected in Frewin, Are We Alone?, and the originals are in the Kubrick Archive, University of the Arts, London.

Brian Aldiss, Billion-Year-Spree [1973], London: Corgi, chs 9-10, 244-325.

Lester del Rey, Galaxy 26.6 (July 1968), 193-4, and Galaxy's editor Frederick Pohl in Film Society Review 5.2 (1970), 23-7. Critical responses are collected in Agel, Making of 2001, and Stephanie Schwam, The Making of 2001: A Space Odyssey, New York: Random House, 2000; several hostile critics afterwards changed their minds. 
in December 1968. The film as a whole was slow, hypnotic and enigmatic. In interviews Kubrick encouraged philosophical speculations about its meaning, while all the time insisting that he did not give explanations. This was Kubrick's explanation, 'on the lowest level', of the final stages of the film:

When the surviving astronaut, Bowman, ultimately reaches Jupiter, this [alien] artifact sweeps him into a field of force or star gate that hurls him on a journey through inner and outer space and finally transports him to another part of the galaxy, where he's placed in a human zoo approximating a hospital terrestrial environment drawn out of his own dreams and imagination. In a timeless state, his life passes from middle age to senescence to death. He is reborn, an enhanced being, a star child, an angel, a superman, if you like, and returns to Earth prepared for the next leap forward of man's evolutionary destiny. ${ }^{10}$

In the long run, it was its mystical aspect which accounted for the cult status of 2001: A Space Odyssey.

2001 offered a vision of progress on the grandest scale, in which space travel is a natural extension of the earliest human technology, and contact with extraterrestrial intelligence triggers a step change in human evolution. On closer examination, however, there is however a darker side to both film and novel: the hints that preparations for nuclear war are more advanced than those for first contact; the emotionless and deceitful human characters; the equally emotionless and deceitful supercomputer HAL 9000 who derails the mission to Jupiter; and the dark fable of the origin of humanity through weaponry and violence in the 'Dawn of Man' sequence. If 2001 is about transcendence, it is equally about the limits that have to be transcended. Sandwiched between the atomic black comedy $\mathrm{Dr}$ Strangelove (1964) and the dystopian A Clockwork Orange (1972), a film that was simply a peon to progress would have been an anomaly in the career of a director whose oeuvre was dominated by films exploring the human capacity for violence and deception. Much of the interest of 2001 for the historian lies in the contrast between its secular and progressive outward message and its more philosophical

10 Stanley Kubrick, 1970 interview with Joseph Gelmis, in Gene D. Phillips, ed., Stanley Kubrick Interviews, Jackson: University of Mississippi Press, 2001, 80104, here 91. 
and pessimistic inner core. This yields insights both into the tensions within western astroculture and into the sources of its decline in the 1970s.

The long-running critical debate about the film has received extensive attention; much of it has been published. ${ }^{11}$ More recently, however, the opening of both the Stanley Kubrick Archive at the University of Arts London and the Arthur C. Clarke Collection at the National Air and Space Museum, Washington, DC has allowed a more thorough historically-based exploration of the making of 2001: $A$ Space Odyssey.12 Using draft novel texts, scripts and screenplays, together with correspondence, research and production materials, and other works by the film's creators, this chapter explores two elements of the film where the ambiguous attitude towards human progress is most marked: on the one hand the threat of nuclear war, and on the other the 'killer ape' model of human origins portrayed in the prologue of 'The Dawn of Man'. 2001 posed questions about the limits to the progress of a nuclear-armed primate on a single planet; it was a film equally about human origins and the human future.

\section{The Atomic Crossroads}

The idea that the invention of the nuclear bomb had brought mankind to a crossroads was part of the cultural architecture of the Cold War. "The first atom bomb tests at Bikini Island in 1946 were code-named 'Operation Crossroads'. In the 1930s English writer H. G. Wells (1866-1946) had characterized contemporary history as 'a race between education an catastrophe', and with the atomic bombing of Japan in August 1945 the moment of choice seemed to have arrived. An editorial in The Times of London on 11 August 1945 warned: 'It must be made impossible for war to begin, or else mankind perishes.' 'We are now faced with the naked choice between world cooperation and world destruction', Britain's Prime Minister Clement Attlee told the House of Commons. The US Secretary of State for War

11 Agel, Making of 2001; Schwam, Making of 2001; Michael Chion, Kubrick's Cinema Odyssey, London: BFI Publishing, 2001; Mark Crispin Miller, '2001: A Cold Descent', Sight and Sound n.s. 4:1 (Jan. 1994), 18-25; Volker, Stanley Kubrick's 2001; Kramer, 2001: A Space Odyssey.

12 Richard Daniels, Peter Kramer and Tatjana Ljujic, eds, Stanley Kubrick: New Perspectives, London: Black Dog Press (forthcoming) presents research based on the Kubrick archive, including Robert Poole, '2001: A Space Odyssey and the Dawn of Man' which is drawn upon for part of the present article. 
Henry Stimson wrote in September 1945 that the present time marked 'the climax of the race between man's growing technical power for destructiveness and [...] his moral power.' Vannevar Bush, President Truman's science advisor, wrote: 'Down one path lies a secret arms race, down the other international collaboration and possibly ultimate control.' Journalist Norman Cousins, in a far-reaching early response, argued that the coming of the atomic bomb 'marked the violent death of one stage in man's history and the beginning of another.' The challenge to abolish war was 'the largest order man has had to meet in his 50,000-odd years on Earth.'13 The wave of public anxiety about the future of civilization in the atomic age was led by the atomic scientists themselves. ${ }^{14}$ Their manifesto was entitled One World or None?, the question mark indicating an inescapable choice. ${ }^{15}$ Britain's atomic scientists produced a similar volume entitled Atomic Challenge; their leading spokesman was the philosopher Bertrand Russell. ${ }^{16}$ Einstein led the American atomic scientists in promoting international control of the bomb and world government as the solution to the dilemma. There was a widespread consensus that human nature had to catch up with technology if it were to have a future. ${ }^{17}$

13 Lawrence S. Wittner, One World or None? A History of the World Nuclear Disarmament Movement Through 1945, Stanford, Stanford University Press, 1993, 248-9; Norman Cousins, 'Modern Man is Obsolete', New York Times, Saturday Review (18 August 1945), 5-9; Scott C. Zeman, "'To See... Things Dangerous to Come to": Life Magazine and the Atomic Age in the United States, 1945-1965', in The Nuclear Age in Popular Media, ed. Dick van Lente, Basingstoke: Palgrave Macmillan, 2012, 53-78; Dolores L. Augustine, '"Learning from War": Media Coverage of the Nuclear Age in the Two Germanies', ibid., 79118; van Lente, 'Nuclear Power, Politics, and a Small Nation', ibid., 154-6. Alice Kimball Smith, A Peril and a Hope: the Scientists' Movement in America, 1945-47, Chicago: Chicago University Press, 1965; Paul Boyer, By the Bomb's Early Light, Chapel Hill, University of North Carolina Press, 1985, paperback edn, 1994; Spencer R. Weart, Nuclear Fear: a History of Images, Cambridge, Harvard University Press, 1988; Wittner, One World or None. Albert Einstein, 'Atomic War or Peace?', Atlantic Monthly (November 1945), reprinted in Out of My Later Years, New York, Philosophical Library, 1950, 18599; Dexter Masters and Katharine Way, One World or None, New York, Federation of Atomic Scientists, 1946. John D. Cockroft, ed., Atomic Challenge: A Symposium, London: Winchester, 1948, xx. North Carolina Press, 1999, 25-37. On the displacement of atomic anxieties in other directions, see Joachim Radkau, Nature and Power: a Global History of the Environment [2002], Cambridge, Cambridge University Press, 2008, 265- 
This sense of mankind at an atomic crossroads prompted an anxious search for alternative scenarios to destruction. The most popular of these, after world government, was spaceflight. 'Man will soon reach the planets unless we first destroy ourselves,' the science fiction writer and philosopher Olaf Stapledon (1886-1950) told Clarke and other members of the British Interplanetary Society in $1948 .{ }^{18}$ It was widely expected that serious space travel would require atomic and not merely liquid-fuelled rockets, making the issue of atomic energy especially sharp. American astronomer and space advocate Carl Sagan (1934-1996), who was approached - unsuccessfully - to be scientific advisor to 2001: A Space Odyssey, wrote: 'The modern rocket [...] will prove to be either the means of mass annihilation through a global thermonuclear war or the means that will carry us to the planets and the stars. ${ }^{19}$ Kubrick and Clarke shared this set of assumptions. 'Space exploration is just about the only activity the human race will turn to as an alternative to blowing itself up,' declared Kubrick on the jacket of the novel of 2001: A Space Odyssey. The statement echoed Clarke's claim in 1948 that with the advent of nuclear weapons interplanetary travel is now the only form of "conquest and empire" compatible with civilization.'20 The leap into space was also a leap to safety.

Concerns about nuclear war lay behind the rapid growth in the late 1950s and early 1960s of the scientific version of the belief in extraterrestrial intelligence. The first serious paper on the subject in a mainstream scientific journal was published in 1959 , and the first attempt at detecting alien radio signals was in

72; Robert R. MacGregor, 'Imagining an Aerospace Agency in the Atomic Age', in Remembering the Space Age, ed. Stephen J. Dick, Washington, DC: NASA, 2008, 55-70. Olaf Stapledon, 'Interplanetary Man?', Journal of the British Interplanetary Society 7.6 (November 1948), 213-33. Carl Sagan, quoted in DeWitt Douglas Kilgore, Astrofuturism: Science, Race, and Visions of Utopia in Space, Philadelphia: University of Pennsylvania Press, 2003, 56.

Copy for cover of the first UK edition of 2001: A Space Odyssey, 1968; Arthur C. Clarke, 'The Challenge of the Spaceship: Astronautics and its Impact upon Human Society', Journal of the British Interplanetary Society 6.3 (December 1946), 66-81, here 72-3; reprinted in The Challenge of the Spaceship, New York: Harper, 1959, \#\#\#-\#\#\#. 
$1961 .{ }^{21}$ Both were founded on the assumption that communicating civilizations were necessarily long-lived, which in turn was based upon the assumption that atomic war was a hazard of the 'technological adolescence' of intelligent species rather than an enduring characteristic of advanced societies. If the search for extraterrestrial intelligence failed to make contact, argued Sagan, 'the most likely explanation [...] is that societies commonly destroy themselves before they are advanced enough to establish a high-power radio-transmitting service.'22 The dangerous period was between the discovery of atomic energy and the migration into space, a period when a culturally immature civilization with the propensity to blow itself up was confined to a single planet. Once this phase was passed there was no limit to the power and longevity of civilizations. Indeed, the immense distances between the stars mean that proponents of extraterrestrial intelligence were positively required to build into their calculations an average lifespan for technological civilizations extending to tens of millions of years if there were to be any reasonable chance of their overlapping in both time and space. Allied civilizations would by definition be both very peaceful and highly advanced. When homo sapiens made contact it was likely to be welcomed into a 'galactic club' provided that it posed no threat to the cosmic peace. ${ }^{23}$ The vision of an Olympian galactic civilization, free from the vice violence of present-day western civilization, was an essential way in which the serious and scientific style of belief in extraterrestrial life sought to distance itself from the 'bug-eyed monster' school of pulp fiction and B-movies and the wilder speculations of ufologists. ${ }^{24}$

21 G. Cocconi \& Philip Morrison, 'Searching for Interstellar Communications;, Nature 184 (19 September 1959), 844-6; A. G. W. Cameron (ed.), Interstellar Communication New York: W. A. Benjamin, 1963.

22 Carl Sagan, 'The Quest for Extraterrestrial intelligence ', in Sagan, Broca's Brain, New York: Coronet, 1980, 324-5. Ronald Bracewell, The Galactic Club: Intelligent Life in Outer Space, San Francisco: W.H. Freeman, 1975; Robert Poole, 'ET and the Bomb', unpublished paper, British Society for the History of Science conference, Exeter, July 2011. Alexander C.T. Geppert, 'Extraterrestrial Encounters: UFOs, Science and the Quest for Transcendence, 1947-1972', History and Technology 28.3 (2012), 33562; Thore Bjørnvig, 'Transcendence of Gravity: Arthur C. Clarke and the Apocalypse of Weightlessness', in Alexander C.T. Geppert, ed., Imagining Outer Space: European Astroculture in the Twentieth Century, Basingstoke: Palgrave Macmillan, 2012, 127-46. 
In an interview with Playboy magazine after the film had come (???) out, Kubrick argued that, while first contact carried a risk of 'severe psychological dislocations', it would most likely enrich society immeasurably. He went on to explain the connection between avoiding nuclear war and alien encounter:

Another positive point is that it's a virtual certainty that all intelligent life must at one stage in its development have discovered nuclear energy. This is obviously the watershed of any civilization; does it find a way to use nuclear power without destruction and harness it for peaceful purposes, or does it annihilate itself?

Any detectable aliens would be bound to have negotiated that watershed, showing that survival was possible; they might even 'give us specific guidelines for our own survival.'25 The solution offered by 2001 was an optimistic one: salvation from the human propensity for war through contact with extraterrestrial intelligence. The outward optimism of the first Space Age was intimately bound up with the darkest fears of the twentieth century, and this was as true for western society as a whole as it was for the makers of 2001.

Kubrick's previous film had been the dark atomic satire Dr Strangelove, made in 1962-63 when the Cold War theology of deterrence was at its height. In it, a false alert of a Soviet attack is set off by a mentally unbalanced American base commander, and the United States embark on a path to nuclear war, propelled not by any great forces of history but by accidents, misjudgments and personality disorders. In the end the bomb drops and mankind is wiped out. 2001 grew out of Dr Strangelove, as Peter Kramer has explained in a succinct discussion of its origins. In one version of the script, Kubrick had experimented with the framing device of a commentary from the point of view of an alien civilization, explaining the end of human civilization as the result of failure to form a world government. ${ }^{26}$ With the 1962 Cuban missile crisis successfully negotiated and the Partial Test Ban Treaty put in place just before the film's release, Kubrick naturally sought to explore the way out of the atomic crossroads. Rejecting invitations to get involved in the movement for peace and nuclear disarmament, he ordered a year's back issues of

\footnotetext{
25 Phillips, Stanley Kubrick Interviews, 52-3.

26 Kramer, 2001: A Space Odyssey, 18-19.
} 
Sky and Telescope magazine and made contact with Arthur C. Clarke, now living in Sri Lanka. ${ }^{27}$

Clarke too had wrestled with the problem of the atomic bomb. He had been in London with colleagues in the British Interplanetary Society when it was under assault from V-2 missiles engineered by former members of the BIS's German counterpart, the Berlin-based Verein für Raumschiffahrt, He was thus in a position to appreciate the contradictions posed by a version of progress based on rocket technology. He had discussed the issues soberly in his 1946 essay 'The Rocket and the Future of Warfare', which was followed a few months later by his manifesto 'The Challenge of the Spaceship'. ${ }^{28}$ The resurgence of science fiction in the United States and Britain in the post-war years saw a plethora of fiction which sought to come to terms with the threat of atomic technology, in much the same way as Clarke had sought to come to terms with rocket technology. Clarke's own early stories belonged to this period as he experienced a rush of inspiration that would provide him with the grand themes that he would rework for years to come. Early on in the preparations for 2001, Kubrick's assistant Roger Caras provided summaries of eleven of Clarke's early short stories from the collection Expedition to Earth for possible use in the film. Six of these contemplate the destruction of a civilization by war, usually atomic. ${ }^{29}$ In 'If I forget thee 0 Earth', colonists on the Moon look back at their home planet: 'Across a quarter of a million miles of space, the glow of dying atoms was still visible, a perennial reminder of the ruined past.'30 In 'Second Dawn' an alien race prematurely acquires the secret of atomic power before attaining the mental maturity to become telepathic and so overcome conflict: 'Alone, perhaps of all the races in the Universe, her people had reached the second cross-roads - and had never passed the first. Now they must go along the

27 Stanley Kubrick Archive, University of the Arts, London (henceforth SKA) SK11/9/97.

28 Clarke, 'The Rocket and the Future of Warfare', RAF Quarterly 17.2 (March 1946), 61-9; and idem, 'Challenge of the Spaceship'; Robert Poole, 'The Challenge of the Spaceship: Arthur C. Clarke and the Origins of Western Astroculture, 19301970', History and Technology 28.3 (2012), 255-80. The six stories of extinction are 'Second Dawn', 'If I Forget Thee, O Earth', 'History lesson' (UK title 'Expedition to Earth'), 'Superiority', 'Loophole', and 'The Sentinel'. 
road that they had missed, and must face the challenge at its end.' It is implied that the road for them will end in atomic war. ${ }^{31}$ The earliest of these stories, 'Loophole', from April 1946, offers a reversal of the scenario of H G Wells' War of the Worlds. A Martian civilization detects the atomic explosions on Earth at the end of the Second World War and decides to set up a monitoring post on the Moon. Fifteen years later mankind develops atomic rockets, at which point a Martian battle fleet assembles to warn Earth: 'These experiments must cease. Our study of your race has convinced us that you are not fitted to leave your planet in the present state of your civilization.' Earth appears to comply but then secretly develops teleportation and wipes the Martians out in a surprise atomic attack. ${ }^{32}$

Among the short stories summarized for Kubrick was 'The Sentinel' - written in 1948 and published three years later - which provided 2001: A Space Odyssey with its pivotal event: the discovery of an alien artifact on the Moon. In the film the excavation of the artifact exposes it to the sun, triggering a signal to its makers that man has reached the Moon and is ready for some assistance to develop further. The original scenario in 'The Sentinel' is altogether darker than 2001, owing more to the Nuclear Age than to the Space Age. The alien artifact resists all attempts to open it, until 'what we could not understand, we broke at last with the savage might of atomic power'. The scientist-narrator realizes that 'we have broken the glass of the fire alarm' and its makers will soon arrive to attend to the blaze. Humankind has reached the atomic crossroads; space travel 'is a double challenge, for it depends in turn upon the conquest of atomic energy and the last choice between life and death.' The story ends as the narrator wonders whether the alien fire brigade will want to assist Earth or to cull its destructive civilization: 'I do not think we will have to wait for long.'33 Caras marked the story: 'Read this'. Kubrick read it and bought the rights. In the spring of 1964 Clarke travelled to New York and met Kubrick. The two men immediately hit it off and set about co-writing a novel, provisionally entitled Journey Beyond the Stars, with which to secure the film deal that produced 2001: A Space Odyssey.

\footnotetext{
$31 \quad$ Ibid., 41.

32 See ibid., 146-52: 'When mankind eventually develops atomic rockets, a Martian battle fleet assembles [...].' 
The events of 2001 take place in a world where atomic power has been applied to rocketry but the nuclear standoff has not yet been resolved. In the early drafts of Journey Beyond the Stars the lunar base is described as 'a closed system, like a tiny working model of Earth itself', redeploying Cold War technology:

Any man who had ever worked in a hardened missile site would have felt at home in Tycho. Here on the Moon were the same arts and hardware of underground living, and protection against a hostile environment; but here at last they had been turned to the purposes of peace.

Tycho Base was more expensive than a Titan site, and this represented something new in the history of Man. After ten thousand years, he had at last found something as interesting as war. ${ }^{34}$

When the chief scientist at the base discusses why the aliens buried their artifact (named 'TMA One') on the Moon rather than on Earth, he makes the connection between atomic power and space travel: 'Perhaps the creatures who built TMA One wanted to make contact only with space-faring societies. They weren't interested in primitive, pre-atomic cultures.' ${ }^{35}$ In the film itself the space sequences open with the orbital ballet, but an early draft of the screenplay makes clear that the first spacecraft that we see are in fact American and Russian one thousand megaton bombs. 'Hundreds of giant nuclear bombs had been placed in perpetual orbit above the Earth', explains a narrator: 'They were capable of incinerating the entire Earth's surface from an altitude of 100 miles.' Such weapons have brought a sinister peace to a rapidly advancing world, but 'but no one could expect it to last forever.'36

The rest of the film outlines how the stalemate ends. The spaceship Discovery voyages to disaster in its search for the beings who have placed the sentinel on the Moon. David Bowman, the last astronaut, like Odysseus, returns home as the sole survivor of his expedition, transformed by the experience of exile. In the film he is symbolically reborn as a 'space baby' or star child, but the book adds another crucial detail: he detonates the orbiting nuclear arsenal because 'he preferred a cleaner sky'. Clarke later wrote that some readers had interpreted this to mean

SKA, SK12/1/1/2 Incomplete novel text (the 'Lucifer text'), 4.1-4.3.

Ibid., 7.12-7.13.

36 SKA, SK12/1/2/1, 'The Athena Screenplay, 26. 
that human civilization was destroyed, although he had intended to indicate that the detonation was harmless and mankind had been saved. 'But now,' he added, in 1972, 'I am not so sure.' Thinking of how Odysseus took revenge on those who had taken over and plundered his estates, Clarke wrote: 'We have wasted and despoiled our own estate, the beautiful planet Earth. Why should we expect any mercy from a returning Star Child? He may judge us all as ruthlessly as Odysseus.' 37

Even without an apocalyptic ending it is possible to detect a strand of nuclear pessimism just below the surface of 2001's allegory of human progress. When an academic fan of the film sent Kubrick a study of the psychological responses of the American public to the October 1962 Cuban missile crisis, which appeared to bring the northern hemisphere close to nuclear war, Kubrick replied with a thoughtful letter: 'One of the more alarming features of the Cuban crisis, to my eyes anyway, was the lack of concern on the part of most of the people [...] who thought of it either as a bluff which they could not take seriously, or else they had an incredible kind of denial-resignation which allowed them to say if it happens it happens.' ${ }^{38}$ In Dr Strangelove the great crisis of human history is navigated by human sleepwalkers, unaware of what is happening, unequipped to cope with the consequences of their own technology. This could equally well describe 2001: $A$ Space Odyssey, except that this time the crisis is the discovery of extraterrestrial intelligence. The human characters in the film are tightly controlled and deceitful (as is the computer HAL) but there are suggestions throughout that more primitive tensions are not far below the surface - in the wary way the American and Russian officials interact at the space station, for example, and in the last astronaut's vengeful advance upon the computer which has just tried to kill him. Homo sapiens may have survived the atomic crossroads to make it into space but his ancient, two-edged human nature has come with him. In the end man is rescued from his primitive self through alien intervention. For those who have watched carefully the prologue to the film, 'The Dawn of Man', however, this will come as no surprise, for this was how it all began.

37 Clarke, Lost Worlds of 2001, 239-40.

38 SKA, SK11/9/100 (correspondence between Kubrick and Irvin Doress). 


\section{Apeman, Spaceman}

The 'Dawn of Man' sequence which opens 2001: A Space Odyssey provides an account of the evolutionary origins of mankind that stakes out the ground for what will happen in the year 2001. In the film it takes the form of a wordless fable, but events were explained in detail in the novel when it appeared. The sequence opens two million years ago on the African savannah. A tribe of hominids is on the verge of dying out in a long drought, kept away from the water hole by a rival tribe and preyed upon by leopards. They live amongst other animals, but have no way of exploiting them: 'In the midst of plenty they were slowly starving to death.' ${ }^{39}$ One day an alien monolith appears and by some mysterious process teaches them to use bone weapons. They attack and kill the leopard, kill the leader of the rival tribe of hominids, and learn to hunt and butcher their prey, setting them on the evolutionary path to humanity with all the ingenious technology of violence. In the novel a linking narrative sketches out the next two million years of human history. After outlining the rise of language, agriculture, technology and civilization it concludes: 'The spear, the bow, the gun and finally the guided missile had given him [man] weapons of infinite range and all but infinite power [...] for ages they had served him well. But now, as long as they existed, he was living on borrowed time.' 40

One famous scene in 2001 symbolized human progress. Having learnt to use bone weapons to hunt game and to kill his rival, the chief hominid (Moonwatcher by name) hurls a bone into the air in triumph, where it spins over and over before the films cuts to the year 2000 and a bone-white orbiting spaceship. One simple and widespread response to this scene is awe at the scale of technological progress achieved by a simple primate, and wonder at the power of evolution. But how far has the man-ape himself evolved? An alternative reading is that technology has outrun human nature - the spaceship is, in both book and screenplay, a nuclear weapon. More pessimistically still, human history was formed in violence and might yet end in it. The big questions about the human future were bound up with

\footnotetext{
39 Clarke, 2001: A Space Odyssey, ch.1. Chapter references are given as editions vary.

$40 \quad$ Clarke, 2001: A Space Odyssey, ch. 6.
} 
those about human origins. Kubrick and Clarke moreover were not the only commentators to connect apeman and spaceman.

From the day in 1961 when NASA sent a chimpanzee into space ahead of any of the famous 'Mercury Seven' astronauts, the figure of the astronaut was mocked by the figure of the ape. 1968 saw the release not only of 2001: A Space Odyssey but also of Planet of the Apes and a collection of science fiction stories entitled Apeman, Spaceman. ${ }^{42}$ The common theme was that homo sapiens had not evolved to keep up with his own technology and faced disaster if he could not adapt - a theme familiar from the response to the atomic bomb a generation before. As long ago as 1930 Olaf Stapledon had written in his novel of future history Last and First Men:

His [man's] primitive nature could no longer cope with the complexity of his environment. Animals that were fashioned for hunting and fighting in the wild were suddenly called upon to be citizens, and moreover citizens of a world-community. At the same time they found themselves possessed of certain very dangerous powers which their petty minds were not fit to use... ${ }^{43}$

In the 1960 edition of his book Adam's Ancestors, British archaelogist Louis Leakey (1903-1972) worried that 'the over-specialization of our brain power made us capable of inventing the means of destruction of our species by atom bombs' ${ }^{44} \mathrm{~A}$ speaker at a well-publicized conference on aggression and war held by the American Anthropological Association in Washington, DC, in 1967 warned: 'Hiroshima and Nagasaki and the nuclear age have changed for all time the relations of warfare to biology and the very existence of man". ${ }^{45}$ In the Nuclear Age the search for the sources of human nature suddenly began to look urgent.

42 Tom Wolfe, The Right Stuff [1979], London: Picador, 1991, ch. 9, 212-37. Sherryl Vint, 'Simians, Subjectivity and Sociality: 2001: A Space Odyssey and Two Versions of Planet of the Apes', Science Fiction Film and Television 2.2 (Fall 2009), 225-50; Harry Harrison and Leon Stovers, eds, Apeman, Spaceman, New York: Doubleday, 1968.

43 Olaf Stapledon, Last and First Men, 1930; Penguin edition 1972, 21-3.

44 Louis Leakey, Adam's Ancestors, 4th edn, London: Methuen, 1960, 217-18.

45 Morton Fried, Marvin Harris and Robert Murphy, eds, War: The Anthropology of Armed Conflict and Aggression, New York: Natural History Press, 1968, 16-21. The conference took place in November 1967, after a controversy over the profession's stance on the Vietnam War had erupted the previous year. 
The Space Age of 1957-72 also saw a surge in studies of fossil man, generating a wave of interest in human origins that almost rivaled interest in the human future. Until the mid-twentieth century it had been expected that that the earliest human remains would be found in Eurasia or the Far East, but in the 1950s and early 1960s discoveries of fossil remains of early human ancestors by Louis and Mary Leakey in eastern Africa and by Raymond Dart in southern Africa established the view that the human species began in Africa. Discoveries of tools in association with the bones fostered the view that human origins had something to do with the discovery of technology, a view first set out in detail by the British Museum's Kenneth Oakley in Man the Tool-maker, published in 1950. The 'new physical anthropology' at the University of Chicago sought to unite studies of human behavior, primate behavior and fossil human remains, and developed the 'man the hunter' thesis, arguing that humankind grew from the social behavior that accompanied the use of tools and weapons. ${ }^{46}$ More controversially, the South African palaeoanthropologist Raymond Dart (1893-1988) claimed to have found evidence of the use of weapons by the distant ancestor australopithecus some two million years ago, long before the growth of the human brain. 'The bloodbespattered, slaughter-gutted archives of human history', he argued, showed that violence was hardwired into human nature. Dart's views were popularized in 1961 in the bestselling book African Genesis by the writer Robert Ardrey (1908-1980), the best-known example of a genre that later became known as 'savannah sociology'. Ardrey's core message was simple: 'Man had emerged from the anthropoid background for one reason only: because he was a killer [...] Far from the truth lay the antique assumption that man had fathered the weapon. The weapon, instead, had fathered the man.' ${ }^{47}$ Man was both tool-maker and weaponmaker: 'from handaxe to hydrogen bomb his best efforts have been spent on the

46 Kenneth Oakley, Man the Tool-maker, London: British Museum, 1950; Donna Haraway, Primate Visions: Gender and Race in the World of Modern Science, London: 1989, chs 6-8; Anne Roe and George Gaylord Simpson, eds, Behavior and Evolution, New Haven, CT: Yale University Press, 1958; Scientific American 'Human Species Issue' 203.3 (September 1960); Richard Lee and Irven DeVore, Man the Hunter, Chicago, IL: Chicago University Press, 1968; Bruce G. Trigger, 'Aims in Prehistoric Archaeology', Antiquity xliv (1970), 26-37.

47 Robert Ardrey, African Genesis, London: Collins, 1961, 29, 158; Nadine Weidman, 'Popularizing the Ancestry of Man: Robert Ardrey and the Killer Instinct', Isis 102.2 (June 2011), 269-99. 
weapon's perfection.' ${ }^{48}$ While Leakey and the academic professionals rejected Dart, Ardrey was his popular champion, offering an eloquent presentation of the 'killer ape' hypothesis which sustained a long-running public controversy over the human propensity for violence. What all these related hypotheses about human origins had in common was a belief that a formative phase in the forging of human nature had taken place on the African savannah in the distant evolutionary past. In 'The Dawn of Man', Kubrick and Clarke were dramatizing an issue that was at the heart of anthropological debate in the 1960s.

As Kubrick and Clarke hammered out the storyline for 2001 through successive drafts they read both Leakey's Adam's Ancestors and Ardrey's African Genesis. ${ }^{49}$ They also discussed plot outlines involving contact between intelligent extraterrestrials and primitive humans beginning in prehistoric Africa, drawing on one of Clarke's early stories, 'Encounter in the Dawn', which had not been amongst those first purchased by Kubrick. ${ }^{50}$ Clarke, together with the film's scientific advisor Frederick Ordway, had dinner with Leakey and his son Richard in New York in November 1965, and Richard visited the film set at Shepperton near London a couple of months later. Louis Leakey was later invited (but declined) to contribute an interview to the prospective documentary prologue. ${ }^{51}$ When the 'Dawn of Man' scenes came to be filmed, Kubrick and his colleagues and actors went to enormous lengths to make the hominids appear realistic, visiting apes in the zoo and the displays on early man in London's Natural History Museum and consulting books, films and even seminars on the latest findings in primatology and ape social behavior. As much effort went into the realism of the prehistoric scenes as into that of the space scenes, for their message was of equal importance.

'The Dawn of Man' began life as a flashback, inserted late in the $1964 \mathrm{draft}$ novel Journey Beyond the Stars to explain the backstory of the aliens which the astronauts are about to meet: they are the descendants of the visitors who started

\footnotetext{
$48 \quad$ Ardrey, African Genesis, 204-5.

49 Clarke, 2001, Part 1; SKA, SK/12/1/1 (novel texts), 12/1/2 (screenplays), 12/8/1/21-3 (voice-over narratives).

$50 \quad$ Clarke, Lost Worlds, 50-2; SKA, SK12/8/1/12.

51 Clarke, Lost Worlds of 2001, 34-5, 39, 50-2; Frederick I. Ordway, '2001: A Space Odyssey in Retrospect', in Science Fiction and Space Futures: Past and Present, ed. Eugene M. Emme, San Diego: American Astronautical Society, 1982, 47-105, here 56; SKA, SK/12/8/1/62 Leakey to Caras, 21 February 1966.
} 
the man-apes on the road to humanity two million years before. In this form, it would have provided a dramatic revelation about the beginning of human progress and prepared the viewer for another assisted evolutionary leap. In the earlier drafts of the novel the man-apes are already violent in an ineffective way before the aliens arrive teach them how to use stones and bones to hunt and butcher their prey. Success improves their diet, leaving them time to socialize and ultimately become human; technology and enterprise bring progress. ${ }^{52}$. In the final scene, preserved in the published novel though not in the film, Moonwatcher's tribe prevail over its rivals not by crude violence but through ritual: they parade the leopard's head on a stick, like a trophy, which so overawes the other man-apes that they are easily routed. It is the combined triumph of ritual and power, not just a tale of animal violence but the first episode in human history. ${ }^{53}$

Clarke had developed his long view of human history in the immediate postwar years under the influence of the bestselling book A Study of History by the British historian Arnold J. Toynbee (1889-1975). Clarke had read Toynbee's books during the war, attended his 1947 public lecture in London on 'The Unification of the World'. He embraced Toynbee's emphasis on the role of creative minorities in driving civilization forwards at crucial points in historical cycles of 'challenge and response', and saw the role of rocket pioneers in his own age in the same light. Just as the renaissance age of exploration had rescued medieval Europe from stagnation and collapse, so the coming Space Age might rescue western civilization

52 "Patchwork text" SKA, SK12/1/1/4, chs 2-6; SK12/1/1/2, part I.

53 The relationship between novel and screenplay is complex. In summary, Clarke and Kubrick agreed to co-write a novel, provisionally entitled Journey Beyond the Stars, to secure a deal with MGM, which was done between April and December 1964. The novel, retitled 2001: A Space Odyssey was then greatly revised and extended, a complex process which ended in April 1966, by which time much of the screenplay had been written and many of the sequences set in space had been filmed. The novel was to have come out before the film but in the event Kubrick held it back while further changes were made to the screenplay, particularly the 'Dawn of Man' section which was filmed last of all in the summer of 1967 . These changes were mostly not reflected in the novel which finally appeared in the summer of 1968, several months after the release of the film. Sections of the discarded novel drafts were printed in Clarke, The Lost Worlds of 2001, London: Sidgwick \& Jackson, 1972. See Poole, 'Dawn of Man'. 
from the cycles of war and self-destruction. ${ }^{54}$ Seen in this light, Moonwatcher's tribe of man-apes is the original creative minority. There was, however, a crucial difference between Toynbee and Clarke. For Toynbee, the cycles of history were essentially a process of spiritual degeneration and renewal, whereas for Clarke civilization was driven by technology, animated by human creativity and enterprise.

Evolution and history are linked in a similar way in the sixth chapter of the novel, 'The Ascent of Man', which bridges the gap between 'The Dawn of Man' and the Space Age. In the novel, Clarke describes how the intervention of the aliens is followed by a long period of technological stasis during which the man-apes' reliance on tools rather than physical strength allows them to evolve into a more dextrous and big-brained human form. They become capable of using language and therefore of acquiring culture and transmitting through the generations their successive discoveries of fire, metal, agriculture, settlement, writing, and religion. By the end of this process 'the toolmakers had been remade by their own tools'. Here Clarke picks up Ardrey's phrase that 'the weapon had fathered the man', a statement about violence, and turns it into a statement about technology and culture. ${ }^{55}$

Kubrick was not happy with Clarke's account of human origins, and in the spring of 1966 he returned to 'The Dawn of Man' section of the draft novel. He objected to the 'silly simplicity' of Clarke's account of how the aliens taught the man-apes through a kind of educational TV: 'it takes away all the magic.'56 As to the 'Ascent of Man' chapter, Kubrick wrote: 'I think this is a very bad chapter and should not be in the book. It is pedantic, undramatic and destroys the beautiful transition from man-ape to 2001.' He was particularly anxious to remove any suggestion that the man-apes had been violent before the arrival of the aliens: 'they do not fight with each other [...] though they are strongly territorial, fighting

$54 \quad$ Clarke, 'Challenge of the Spaceship'; Arnold J. Toynbee, 'The Unification of the World and the Change in Historical Perspective', in his Civilization on Trial Oxford: Oxford University Press, 1948, 63-96. This argument is developed in Poole, 'Challenge of the Spaceship'. the title of Jacob Bronowski's 1973 BBC TV history of science and civilization, The Ascent of Man. 
and killing has not entered significantly into their lives.' Violence and tool-weapons had to arrive together. ${ }^{57}$ Kubrick delayed the publication of the novel, facing down threats of legal action from Clarke's agent, while he worked out a cinematic way of conveying the ape-man transition and integrating it with the rest of the film.

Kubrick's solution was to use his own directorial imagination. The whole 'Ascent of Man' narrative was summed up in the single cut from bone to spaceship. The film was given a thematic unity by repeat appearances of the monolith - on the Moon, in space, and during the astronaut's final transformation to 'star child' accompanied by repeated images and theme music to convey a transcendent sense of evolutionary progress. In May 1967, as he at last prepared to film the 'Dawn of Man' sequence, Kubrick cut Clarke's complex attempts to narrate the rise of civilization and produced a simpler screenplay which reproduced large chunks of Ardrey's African Genesis:. 'Man had emerged from the anthropoid background for one reason only: because he was a killer,' ran the narrative voiceover. ${ }^{58}$ Afterwards, explaining his next film, A Clockwork Orange, Kubrick continued to press the killer ape hypothesis. 'It's simply an observable fact that all of man's technology grew out of his discovery of the tool-weapon,' he told one interviewer. 59 'I'm interested in the brutal and violent nature of man because it's a true picture of him,' he explained to the New York Times, 'and any attempt to create social institutions on a false view of the nature of man is probably doomed to failure.' 60

In 2001: A Space Odyssey, then, while Kubrick was offering enthralling visions of space travel and evolutionary progress as a way out of the nuclear age, he was also still worrying away at the issues of war and violence that had animated $\mathrm{Dr}$ Strangelove and which fed through into his later work. For Clarke, 2001 was mainly about human progress; for Kubrick, it grew to be equally about human nature.

$57 \quad$ Clarke, Lost Worlds, 48; Kramer, 2001: A Space Odyssey, 59-65. Dawn of Man notes, 30 May 1967, SKA, SK12/8/1/23; Ardrey, African Genesis, 29.

$59 \quad$ Phillips, Stanley Kubrick Interviews, 152.

60 Craig McGregor, 'Nice Boy from the Bronx?', New York Times (30 January 1972), D1, quoted in "The Hechinger Debacle" at www.visualmemory.co.uk/amk/doc/0037.html (accessed 27 January 2014). 


\section{The Myth of Progress}

The mid-twentieth century belief that the human future lay in space travel has been identified by De Witt Douglas Kilgore as 'astrofuturism', the belief that space travel was the key to a future of unlimited human progress and fulfillment. Kilgore contextualized and qualified astrofuturism by demonstrating that it was founded on a color-blind, commonwealth-style outlook whose appeal was less universal than its language. 2001: A Space Odyssey was the cultural peak of astrofuturism, with its transcendent vision of an evolutionary leap into space. But this vision was bound up with anxieties about the limits faced by a hi-tech nuclear-armed primate confined to a single planet, illustrating further the historical context of astrofuturism.

The authors of 2001: A Space Odyssey were both aware of the connections and tensions between the Space Age and the Nuclear Age. Clarke was always concerned about the possibility that the leap into space would be delayed by a failure of political imagination or even cut off by nuclear war, as expressed in his early stories. Clarke also perceived that even if man made it to the stars, nostalgia for the home planet would remain a powerful force. ${ }^{61}$ One of the ironies of astrofuturism was that by measuring homo sapiens against a far-off peak of technological progress it made him appear to be still in infancy. 'What is the ape to man?' asked Friedrich Nietzsche in Thus Spake Zarathustra, and answered himself: 'A laughing-stock, a thing of shame. And just the same shall man be to the Superman [...] man is more of an ape than any of the apes. ${ }^{62}$ In a promotional essay for 2001 Clarke compared the future impact of the discovery that homo sapiens was only one junior intelligent species among many in the cosmos to the shock of the nineteenth-century discovery that he was only part of the animal kingdom. ${ }^{63}$ In his long interview with Playboy magazine Kubrick affirmed: 'In the deepest sense, I believe in man's potential and in his capacity for progress.' But he went on to speak of the need to 'cure' the deep irrationality in man, as identified in Dr Strangelove, in order to allow progress to happen. He also acknowledged the

61 See, respectively, his short stories 'Against the Fall of Night', 'The Star', and 'If I Forget Thee, O Earth', variously anthologized.

62 Friedrich Nietzsche, Thus Spake Zarathustra (1883-5), Prologue, sections 3 and 4, at http://www.gutenberg.org/ebooks/1998

63 Clarke, 'The Universe Around Us', draft article (1966) in SKA, SK/12/8/1/14. 
concerns of physicist Freeman Dyson, author of an early paper on the detection of extraterrestrial intelligence, that the safest response to any alien communication would be to ignore it: 'Intelligence may be a cancer of purposeless technological exploitation, sweeping across a galaxy as irresistibly as it has swept across our own planet.' 64 The faith in progress was haunted by an awareness of how easily it could all go horribly wrong.

Clarke and Kubrick, for all their different emphases, shared a vision of evolutionary progress. Crucially, this vision was grounded in specific arguments about human nature and history. They believed in the mediating role of human agency, and they worked to induce the current generation of humans to sense their place in history and realize their evolutionary potential. This might seem like a modest dash of humanism in an otherwise grandiose project but it has to be compared with the hardline astrofuturism propounded by the German-American community of former V-2 engineers such as Krafft A. Ehricke, Ernst Stuhlinger and Wernher von Braun. ${ }^{65}$ Ehricke, for instance, formulated 'three fundamental laws of astronautics' (the formulation echoing Asimov's three laws of robotics and Newton's laws of motion) which essentially claimed that space was human destiny and there was no limit to human expansion. 'The concept of space travel disregards national borders, refuses to recognize differences of historical or ethnological origin, and penetrates the fiber of one sociological or political creed as fast as that of the next,' wrote Ehricke in the wake of Sputnik. 'Nobody and nothing under the natural laws of this universe can impose any limitations on man except man himself.' 66 In this totalizing vision space travel existed beyond history and unhampered by any contradictions of human nature; lesser species, one senses, had better watch out. In 2001: A Space Odyssey space travel was placed firmly within human history, albeit in a perspective so long that it was not easy to recognize, and equally firmly in juxtaposition to a human nature that by no means guaranteed homo sapiens a future, whether on Earth or in space.

\footnotetext{
64 Phillips, Stanley Kubrick Interviews, 68, 53-4.

65 Kilgore, Astrofuturism.

66 Krafft A. Ehricke, 'The Anthropology of Astronautics', Astronautics 2.4 (November 1957), 26-7, and 65-8, reprinted in Marsha Freeman, Krafft Ehricke's Extraterrestrial Imperative, Burlington, Ontario: Apogee Books, 2009,119-26.
} 
While Clarke and Kubrick's understanding of the leap into space was historically based, in the film it was conveyed using the structures and techniques of myth. ${ }^{67}$ The title of 2001: A Space Odyssey was a direct reference to the myth of Odysseus, the exiled warrior, returning home transformed by his experiences to set his homeland to rights. On the long voyage to Jupiter, the astronaut Bowman reads accounts of past explorations by Magellan and Cook, 'and he began to read the Odyssey, which of all the books spoke to him most vividly across the gulfs of time.' ${ }^{68}$ Clarke and Kubrick had read Joseph Campbell's treatise on myth The Hero With a Thousand Faces while preparing the novel. 'We set out with the very deliberate intention of creating a myth', explained Clarke afterwards. 'The Odyssean parallel was clear in our minds from the very beginning, long before the title of the film was chosen ... All the mythical elements in the film - intentional and otherwise - help to explain the extraordinarily powerful responses that it has evoked from audiences and reviewers.' ${ }^{69}$ Clarke had used the metaphor of Odysseus in several earlier works on space, and told a press conference that the word 'odyssey' was used in the title to avoid its being pigeon-holed as science fiction. ${ }^{70}$ Elsewhere, Clarke described the film as 'a realistic myth', while for Kubrick it was 'a mythological documentary': 'If 2001 has stirred your emotions, your subconscious, your mythological yearnings, then it has succeeded.'71. As well as Odysseus, the returning wanderer, there are strong echoes (in 'The Dawn of Man') of the biblical myth of Cain, son of Adam, who slays his brother Abel, and (in the transformation of spaceman into 'star child') of Nietzsche's theme of man and

David G. Hoch, 'Mythic Patterns in 2001: A Space Odyssey', Journal of Popular Culture 4.4 (Spring 1970/71), 961-5; Philip Kuberski, 'Kubrick's Odyssey: Myth, Technology, Gnosis', Arizona Quarterly 64.3 (Autumn 2008), 51-73; Joseph Campbell, 'The Moonwalk: the Outward Journey' (1970) in Joseph Cambell, Myths to Live By, New York, Viking Press, 1972, 233-49.

68 Clarke, 2001: A Space Odyssey, 115

69 Clarke, Lost Worlds, 34; Clarke, 'The Myth of 2001' [1969], in Report on Planet Three, 247-9; Joseph Campbell, The Hero With a Thousand Faces New York: World Publishing, 1968. Space (1947/1953), New York, NEL edn, 1968, 97 (ch. 19); Alexander Walker, The Film Director as Superstar New York, Doubleday, 1970, 39. 
superman in Thus Spake Zarathustra - the inspiration for the Strauss fanfare of the same name which Kubrick chose as the 2001 theme music. ${ }^{72}$

The film's quasi-religious invocation of space travel as a kind of evolutionary progress was welcomed by most astrofuturists, and popularized by Clarke in a slew of promotional articles. ${ }^{73}$ By refusing to show actual aliens it distanced itself effectively from UFO panics and sci-fi horror movies alike and aligned itself with the newly respectable scientific perspective on the search for extraterrestrial intelligence. It also aligned itself with the emphasis in Space-Age Christianity on the transcendence of God, free of any particular time, place or physical form. ${ }^{74}$ The Roman Catholic Church in the United States conferred its 1968 award for 'Best Film of Educational Value' on '2001: A Space Odyssey, citing 'the scope of its imaginative vision of man - his origins, his creative encounter with the universe, and his unfathomed potential for the future. ${ }^{75}$ Kubrick and Clarke, atheists both, joked that the studio had unwittingly funded 'the first $\$ 10 \mathrm{~m}$ religious movie'; one critic described it as 'a shaggy God story'. ${ }^{76}$ Among those offering favorable commentaries on the film were a Jesuit priest and a senior rabbi. 2001 provides evidence for the developing argument that astrofuturism has many of the characteristics of religious faith. ${ }^{77}$

The fit between progress, religion and myth in 2001 was facilitated by the model of externally assisted evolution adopted by Clarke and Kubrick. The concept of evolution as an internally-driven forward tide of progress had been consistently

Herbert Glass, 'Also Sprach Zarathustra' at the LA Phil website, http://www.laphil.com/philpedia/music/also-sprach-zarathustra-richard-strauss (accessed 17 March 2014); Timothy E. Scheurer, 'Kubrick vs. North: The Score for "2001: A Space Odyssey"', Journal of Popular Film \& Television 25.4 (Winter 1998), 172-82; David W. Patterson, 'Music, Structure and Metaphor in Stanley Kubricks's 2001: A Space Odyssey', American Music 22.3 (Fall 2004), 444-74. Kubrick Archive SKA, SK12/8/1/11, for example Clarke's typescript of an article for Vogue Magazine, 'The World of 2001'. God: The Sacred, the Profane, and the American Space Program, 1957-1975, Baltimore, MD: Johns Hopkins University Press, 2013, 44-70.

Agel, Making of 2001, 327.

Baxter, Stanley Kubrick, 210; Agel, Making of 2001, 327, 244.

Agel, Making of 2001, 31-5, 55-7; Frewin, Are We Alone?, 131-40; Gabriel McKee, The Gospel According to Science Fiction, Louisville, Kentucky: John Knox Press, 2007, 23-5, 39, 150, 178; Bjørnvig, 'Transcendence of Gravity'; Roger D. Launius, 'Escaping Earth: Human Spaceflight as Religion', Astropolitics 11.1-2 (2013), 45-64. 
rejected by religious thinkers since Darwin's day. ${ }^{78}$ The preferred alternative, in both history and evolution, was a cyclical model of progress in which material forces can produce changes within limits but are not sufficient to achieve truly transformative change. In the cyclical model, as the historian of evolution Peter Bowler has explained 'the origin of each new phase of human development - and hence the origin of the human race itself - was not the predictable outcome of a universal trend running through the whole sequence. [...] The origin of nations, like the origin of species, represented an essentially mysterious injection of creative power. ${ }^{.79} \mathrm{~A}$ 'mysterious injection of creative power' is exactly the role of the alien monolith in 2001: A Space Odyssey. It intervenes two million years ago in Africa when the man-apes are threatened with tribal extinction, and again in the year 2001 when homo sapiens is sleepwalking towards nuclear extinction. In between lies one vast cycle of history - vast on the human scale, but not on the cosmic scale - during which humans have achieved much but come to the end of their earthly road. They require assistance from more advanced species if they are safely to negotiate the atomic crossroads and move on to a higher plane of existence. What 2001: A Space Odyssey offered in 1968, then, was not a law of progress but a myth of progress. This was evident in Kubrick's replacement of Clarke's 'Ascent of Man' narrative with the single cut from bone to spaceship. The film's technological realism gave it credibility with space buffs but its core appeal was accounted for by its use of a mythic structure, harnessed to the cause of progress.

As a final point, 2001: A Space Odyssey can be viewed in its historical context, Present-day periodization often telescopes the period 1945-89 into a single 'Cold War', dominated by superpower conflict on the grand scale in politics, war and space. There was, however, a middle period, between the Cuban missile crisis of late 1962 and the onset of the 'Second Cold War' in 1979-80. During which there were serious hopes of east-west accommodation and even convergence, accompanied by large-scale projects which appeared to have the potential to

Peter J. Bowler, Theories of Human Evolution: A Century of Debate, 1844-1944, Oxford: Oxford University Press, 1987. Neither model, of course, was properly Darwinian. 
change the conditions of human existence: treaties to regulate the nuclear arms race, space programs to escape and understand the Earth, and in the 1970s international measures to tackle global environmental problems.. ${ }^{80} 2001$ belongs to this middle stage of the long Cold War. Its astrofuturist utopianism originated in the classic Cold War of 1945-63 as western culture reached for alternatives to nuclear extinction: atoms for peace, space travel, and contact with extraterrestrial intelligence. But behind these utopias lay the fear that, with the atomic bomb, technology had breached the limits of what could be safely entrusted to a semievolved primate on a small planet. This combination of anxiety and idealism had its roots in the Nuclear Age and took flight during the Space Age. The Apollo years of 1968-72 were also the years of the environmental renaissance, linked to the first photos of Earth from space, and of the 'limits to growth' movement, linked to the advent of systems-based world modeling. Their solutions were Earth-based rather than space-based, and often social rather than technological, but they shared with 2001 the diagnosis that, on Earth at least, homo sapiens had reached its limits.

Agel, Jerome, The Making of Kubrick's 2001, New York: Signet, 1970.

Aldiss, Brian, Billion-Year-Spree, London: Weidenfield, 1973.

Alexander Walker, The Film Director as Superstar New York, Doubleday, 1970

Ardrey, Robert, African Genesis, London: Collins, 1961.

Augustine, Dolores L., 'Learning from War" Media Coverage of the Nuclear Age in the Two Germanies', in van Lente, The Nuclear Age in Popular Media;

Baxter, John, Stanley Kubrick: A Biography, London: Harper Collins, 1997.

Bizony, Piers 2001: Filming the Future, London: Aurum Press, 1994.

Bizony, Piers, The Making of Stanley Kubrick's 2001: A Space Odyssey, Cologne: Taschen, 2014.

Bjørnvig, Thore, 'Transcendence of Gravity: Arthur C. Clarke and the Apocalypse of Weightlessness', in Alexander C.T. Geppert, ed., Imagining Outer Space: European

Astroculture in the Twentieth Century, Basingstoke: Palgrave Macmillan, 2012.

Bowler, Peter J., The Invention of Progress: The Victorians and the Past, Oxford: Oxford University Press, 1989.

Bowler, Peter J., Theories of Human Evolution: A Century of Debate, 1844-1944, Oxford: Oxford University Press, 1987.

Boyer, Paul, By the Bomb's Early Light, Chapel Hill, University of North Carolina Press, 1985, paperback edn, 1994.

Bracewell, Ronald, The Galactic Club: Intelligent Life in Outer Space, San Francisco: W. H. Freeman, 1975.

Campbell, Joseph, 'The Moonwalk: the Outward Journey' (1970) in Cambell, Myths to Live By, New York, Viking Press, 1972.

80

See the contributions in The Surveillance Imperative: The Rise of the Geosciences during the Cold War, ed. Simone Turchetti and Peder Roberts, Basingstoke: Palgrave Macmillan, 2014. 
Castle, Alison, The Stanley Kubrick Archive, London: Taschen, 2005.

Chion, Michael, Kubrick's Cinema Odyssey, London, BFI Publishing, 2001.

Clarke, Arthur C., 2001: A Space Odyssey, London: Hutchinson, 1968.

The Lost Worlds of 2001, London: Sidgwick \& Jackson, 1972

Greetings, Carbon-Based Bipeds! London: Harper Collins, 1999.

'The Challenge of the Spaceship: Astronautics and its Impact upon Human Society', Journal of the British Interplanetary Society 6,3 (December 1946), 66-81.

'The Rocket and the Future of Warfare', RAF Quarterly 17, 2 (March 1946), 61-9.

Prelude to Space (1947/1953), New York: NEL, 1968.

'Extra-Terrestrial Relays: Can Rocket Stations Give World-wide Radio Coverage?', Wireless World 51.10 (October 1945), 305-8.

Report on Planet Three, London: Gollancz, 1972.

Cockroft, John D., ed., Atomic Challenge: A Symposium, London: Winchester, 1948.

Cousins, Norman, 'Modern Man is Obsolete', New York Times, Saturday Review, 18 Aug. 1945.

Daniels, Richard, Kramer, Peter, and Ljujic, Tatjana, eds, Stanley Kubrick: New Perspectives, London, Black Dog Press (forthcoming).

Ehricke, Krafft A., 'The Anthropology of Astronautics', Astronautics 2.4 (November 1957), 26-7 \& 65-8, reprinted in Marsha Freeman, Krafft Ehricke's Extraterrestrial Imperative, Burlington, Ontario: Apogee Books, 2009.

Einstein, Albert, 'Atomic War or Peace?', Atlantic Monthly (November 1945), in Out of My Later Years, New York: Philosophical Library, 1950, 185-99.

Frayling, Christopher, The 2001 File: Harry Lange and the Design of the Landmakr Science Fiction Film, London: Reel Art Press, 2015.

Frewin, Antony, Are We Alone? The Stanley Kubrick Extraterrestrial Intelligence Interviews, London: Elliott and Thompson, 2005.

Fried, M., Harris, M., \& Murphy, R., eds, War: The Anthropology of Armed Conflict and

Aggression, New York: Natural History Press, 1968.

Geppert, Alexander C. T., 'Extraterrestrial encounters: UFOs, science, and the quest for transcendence, 1947-72', History and Technology 28, 3 (2012), 335-62.

Haraway, Donna, Primate Visions: Gender and Race in the World of Modern Science, London: 1989.

Harrison, Harry, and Stovers, Leon, eds, Apeman, Spaceman, New York: Doubleday, 1968 (paperback edition Harmondsworth: Penguin, 1972).

Hoch, David G., 'Mythic Patterns in 2001: A Space Odyssey', Journal of Popular Culture 4.4 (Spring 1970/71), 961-5.

Kilgore, De Witt Douglas, Astrofuturism: Science, Race and Visions of Utopia in Space, Philadelphia: University of Pennsylvania Press, 2003.

Kirby, David, Lab Coats in Hollywood: Science, Scientists and Cinema, Cambridge, MA: MIT Press, 2011.

Kolker, Robert Phillip, ed., Stanley Kubrick's 2001: A Space Odyssey: New Essays, Oxford: Oxford University Press, 2006.

Kramer, Peter, 2001: A Space Odyssey, Basingstoke: Palgrave Macmillan, 2010.

Kuberski, Philip, 'Kubrick's Odyssey: Myth, Technology, Gnosis', Arizona Quarterly 64.3

(Autumn 2008), 51-73.

Leakey, Louis, Adam's Ancestors, fourth edition, London: Methuen, 1960.

Lee, Richard, and DeVore, Irven, Man the Hunter, Chicago, IL: Chicago University Press, 1968.

Lente, Dick van, 'Nuclear Power, Politics, and a Small nation', in van Lente, The Nuclear Age in Popular Media, 149-73.

Lente, Dick van, ed., The Nuclear Age in Popular Media, London, Palgrave Macmillan, 2012. MacGregor, Robert R., 'Imagining an Aerospace Agency in the Atomic Age', in Remembering the Space Age ed. Stephen J. Dick, Washington, DC, NASA, 2008, 5570. 
Masters, Dexter, \& Way, Katharine, eds, One World or None, New York: Federation of Atomic Scientists, 1946.

McAleer, Neil, Odyssey: The Authorized Biography of Arthur C. Clarke, London: Victor Gollancz 1992.

McCurdy, Howard E., Space and the American Imagination, Washington, DC: Smithsonian Institution Press, 1997.

McKee, Gabriel, The Gospel According to Science Fiction, Louisville, Kentucky: John Knox Press, 2007

Miller, Mark Crispin, '2001: A Cold Descent', in Depth of Field: Stanley Kubrick, Film, and the Uses of History, ed. Geoffrey Cocks et. al., Madison, University of Wisconsin Press, 2006.

Oliver, Kendrick, To Touch the Face of God: The Sacred, the Profane, and the American Space Program, 1957-1975, Baltimore: Johns Hopkins University Press, 2013.

Ordway, Frederick I., '2001: A Space Odyssey in Retrospect', in Science Fiction and Space Futures: Past and Present, ed. Eugene M. Emme, San Diego: American Astronautical Society, 1982, 47-105.

Patterson, David W., 'Music, Structure and Metaphor in Stanley Kubricks's 2001: A Space Odyssey', American Music 22.3 (Fall 2004), 444-74.

Phillips, Gene D., ed., Stanley Kubrick Interviews, Jackson: University of Mississippi Press, 2001.

Pohl, Frederick, Review of 2001: A Space Odyssey in Film Society Review 5,2 (1970), 23-7. Poole, Robert, 'ET and the Bomb', unpublished paper, British Society for the History of Science conference, Exeter, July 2011.

Poole, Robert, 'The Challenge of the Spaceship: Arthur C. Clarke and the Origins of Western Astroculture, 1930-1970', History and Technology 28.3 (2012), 255-80.

Poole, Robert, '2001: A Space Odyssey and the Dawn of Man', in Daniels, Stanley Kubrick: New Perspectives, pp. 174-97.

Radkau, Joachim, Nature and Power: a Global History of the Environment, 2002, English edn, Cambridge, Cambridge University Press, 2008.

Rey, Leicester del, Review of 2001: A Space Odyssey, Galaxy 26, 6 (July 1968), 193-4.

Roe, Anne, and Simpson, George Gaylord, eds, Behavior and Evolution, New Haven: Yale University Press, 1958.

Roger D. Launius, 'Human Spaceflight as Religion in the Aftermath of the Space Race', unpublished paper at the 'Envisioning Limits' conference, Berlin, 2012

Sagan, Carl, Broca's Brain, New York: Random House, 1980.

Schwamm, Stephanie, The Making of 2001: A Space Odyssey, New York: Random House, 2000.

Scientific American, 'Human Species Issue' 203.3 (September 1960).

Smith, Alice Kimball, A Peril and a Hope: the Scientists' Movement in America, 1945-47, Chicago: Chicago University Press, 1965;

Stapledon, Olaf, 'Interplanetary Man?', Journal of the British Interplanetary Society 7.6 (November 1948), 213-33.

Stork, David G., ed., Hal's Legacy: 2001's Computer as Dream and Reality, Cambridge, MA: MIT Press, 1997.

The Earth Under Surveillance, ed Simone Turchetti et. al.,

Timothy E.Scheurer, 'Kubrick vs. North: The Score for "2001: A Space Odyssey"', Journal of Popular Film \& Television 25:4 (Winter 1998) 172-182

Trigger, Bruce G., 'Aims in Prehistoric Archaeology', Antiquity xiv (1970), 26-37.

van Lente, Dick, ed., The Nuclear Age in Popular Media ed., London, Palgrave Macmillan, 2012.

Turchetti, Simone, and Roberts, Peder, eds, The Surveillance Imperative. The Rise of the Geosciences during the Cold War, London: Palgrave, forthcoming.

Vint, Sherryl, 'Simians, Subjectivity and Sociality: 2001: A Space Odyssey and Two Versions of Planet of the Apes', Science Fiction Film and Television 2.2 (Autumn 2009), 22550. 
Volker, Robert, ed., Stanley Kubrick's 2001: A Space Odyssey: New Essays, Oxford: Oxford University Press, 2006.

Wang, Jessica, American Science in an Age of Anxiety, Chapel Hill, University of North Carolina Press, 1999.

Weart, Spencer R., Nuclear Fear: a History of Images, Cambridge, Harvard University Press, 1988.

Weidman, Nadine, 'Popularizing the Ancestry of Man: Robert Ardrey and the Killer Instinct', Isis 102.2 (June 2011), 269-99.

Wittner, Lawrence S., One World or None? A History of the World Nuclear Disarmament Movement Through 1945, Stanford, University of California Press, 1993.

Wolfe, Tom, The Right Stuff [1979], London: Picador, 1990.

Zeman, Scott C., '"'To See ... Things Dangerous to Come to": Life Magazine and the Atomic Age in the United States, 1945-1965', in van Lente, 53-78. 